Jurnal Basicedu Volume 4 Nomor 2 April 2020 Hal.280-287

JURNAL BASICEDU

Research \& Learning in Elementary Education

https://jbasic.org/index.php/basicedu

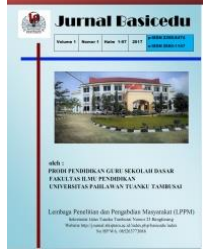

\title{
PENGARUH MODEL PEMBELAJARAN KOOPERATIF TIPE MAKE A MATCH TERHADAP KEMAMPUAN KOMUNIKASI MATEMATIS SISWA SEKOLAH DASAR
}

\author{
Ayu Fitri ${ }^{1}$, Ismaya Dewi ${ }^{2}$ \\ Universitas Buana Perjuangan Karawang, Jawa Barat, Indonesia ${ }^{1,2}$ \\ Email: ayufitri@ubpkarawang.ac.id, ismayadewi22@gmail.com ${ }^{2}$
}

\begin{abstract}
Abstak
Penilitian ini dilaksanakan di kelas III SDN Kondangjaya III Kabupaten Karawang, yang bertujuan untuk melihat perbedaan pengaruh pembelajaran menggunakan model pembelajaran kooperatif tipe make a match dengan yang tidak menggunakan model pembelajaran kooperatif tipe make a match terhadap kemampuan komunikasi matematis siswa. Jenis Penelitian ini adalah Eksperimen. Desain yang digunakan dalam penelitian adalah Nonequivalent Kontrol Group Design. Populasi yang digunakan adalah siswa kelas III SDN Kondangjaya I, Sampel pada penelitian ini kelas III F sebagai eksperimen dan kelas III E sebagai kelas kontrol. Intrumen tes yang digunakan untuk mengetahui kemampuan komunikasi matematis siswa dengan menggunakan tes berbentuk uraian. Hasil analisis data pada pretest kelas eksperimen nilai yang didapat masih rendah nilai yang diperoleh sebesar 38.20, sedangkan pada kelas kontrol adalah 39.00. Setelah dilakukan treatment pembelajaran menggunakan model pembelajaran kooperatif tipe make a match. Hasil analisis pada posttest kelas eksperimen diperoleh bahwa kemampuan komunikasi matematis siswa meningkat dengan ratarata menjadi 76.90, sedangkan pada kelas kontrol diperoleh nilai rata-rata 71.53. Berdasarkan uji t yang dilakukan diperoleh sig (2-tailed) $<0.05$ yang artinya terdapat perbedaan terhadap kemampuan komunikasi matematis siswa.
\end{abstract}

Kata Kunci : Pembelajaran kooperatif tipe make a match, Kemampuan Komunikasi Matematis

\begin{abstract}
This research was conducted in class III Kondangjaya Elementary School Karawang. Which aims to see the difference influence of learning using cooperative learning type make a match with doesn't use cooperative learning type make a match towards mathematical communication skills. Kind of this research using experiment and used nonequivalent control group design. The population used is students class III Kondangjaya III elementary school with samples in this study class III F as an experiment and class III E as a control class. The results of data analysis on the pretest class test the value received was still low a value gained by 38.20, while the control class was 39.00. After treatment using cooperative learning model type make a match. An analysis of the class's posttest found that the ability to communicate mathematically with the students increased to an average of 76.90, while in the control class earned an average of 71.53. Based on a sig (2-tailed) $<0.05$, it's likely there's a difference between the student's mathematical communication abilities.
\end{abstract}

Keyword: Cooperative Learning Type Make A Match, Mathematics Communication Ability

@ Jurnal Basicedu 2020

$\triangle$ Corresponding author :

Address : -

Email :-

ISSN 2580-3735 (Media Cetak)

Phone :- 
281 Pengaruh model pembelajaran kooperatif tipe Make A Match terhadap kemampuan komunikasi matematis siswa sekolah dasar - Ayu Fitri, Ismaya Dewi

\section{PENDAHULUAN}

Manusia adalah makhluk sosial yang tidak luput dari interaksi, interaksi antar makhluk hidup dapat berupa kegiatan berkomunikasi. Menurut Dhinie (dalam Inten, 2017:111) menyebutkan bahwa "komunikasi adalah perpindahan suatu arti melalui suara, tanda, bahasa tubuh, dan simbol". Ketika semua orang berkumpul maka disitu akan terjadi sebuah komunikasi baik verbal maupun non verbal, Seperti kegiatan di sekolah yakni KBM (Kegiatan Belajar Mengajar). Kegiatan belajar mengajar adalah kegiatan berkomunikasi. komunikasi antara guru dengan siswa, siswa dengan guru, dan siswa dengan siswa adalah kegiatan interaksi yang dilakukan di dalam kelas. Kemampuan komunikasi ini perlu jika diterapkan sejak dini di sekolah dasar. Hampir semua pembelajaran yang ada di sekolah membutuhkan kemampuan komunikasi. Salah satu pembelajaran yang membutuhkan kemampuan komunikasi adalah pembelajaran matematika. Sebagaimana yang dijelaskan oleh Daryanto dan Raharjo (dalam Purnama, 2017:46) "Matematika dipelajari oleh siswa ketika di sekolah untuk membekali mereka dengan beberapa kompetensi antara lain kemampuan berpikir logis, analistis, sistematis, kritis, dan kreatif serta kemampuan bekerjasama."

Kemampuan komunikasi juga merupakan kemampuan mendasar yang harus dikuasai siswa dalam pelajaran matematika. Dalam Peraturan Menteri Pendidikan nasional No. 22 Tahun 2006 (Hodiyanto, 2017:10) menyebutkan bahwa "salah satu tujuan pembelajaran matematika adalah supaya siswa memiliki kemampuan mengkomunikasikan gagasan dengan simbol, tabel, diagram, atau media lain untuk memperjelas keadaan atau masalah". Adapun tujuan pembelajaran matematika menurut Akib (2015:1) yakni: (1) Melatih cara berpikir dan bernalar dalam menarik kesimpulan, misalnya melalui kegiatan penyelidikan, eksplorasi, eksperimen, menunjukkan kesamaan, perbedaan, konsistensi dan inkonsistensi; (2) Mengembangkan aktivitas kreatif yang melibatkan imajinasi, intuisi, dan penemuan dengan mengembangkan pemikiran divergen, orisinil, rasa ingin tahu, membuat prediksi dan dugaan, serta mencoba-coba; (3) Mengembangkan kemampuan memecah-kan masalah; (4) Mengembangkan kemampuan menyampaikan informasi atau mengkomunikasikan gagasan antara lain melalui pembicaraan lisan, grafik, peta, diagram, dalam menjelaskan gagasan tersebut

Komunikasi matematis menjadi bagian penting dalam pembelajran matematika karena melalui komunikasi siswa dapat menyampaikan ide-ide dan pengetahuan-pengetahuan yang telah mereka terima. Menurut Greenes dan Schulman (dalam Sari, 2017:87) mengemukakan bahwa: (1) kekuatan sentral bagi siswa dalam merumuskan konsep dan strategi matematik, (2) modal keberhasilan bagi siswa terhadap pendekatan dan penyelesaian dalam eksplorasi dan investigasi matematik, (3) wadah bagi siswa dalam berkomunikasi dengan temannya untuk memperoleh informasi, membagi pikiran dan penemuan, curah pendapat, menilai serta mempertajam ide untuk meyakinkan orang lain.

Kegiatan kemampuan komunikasi matematis siswa dapat berupa menyampaikan simbol matematika dengan sebuah kalimat lengkap. Baroody (dalam Sari, 2017:87) juga mengemukakan dua alasan komunikasi perlu ditumbuh kembangkan dalam pembelajaran matematika yakni Pertama, matematika merupakan bahasa yang esensial bagi matematika itu sendiri. Matematika bukan hanya alat berpikir yang membantu peserta didik untuk menemukan pola, 

matematis siswa sekolah dasar - Ayu Fitri, Ismaya Dewi

memecahkan masalah dan menarik kesimpulan, tetapi juga alat untuk mengomunikasikan pikiran peserta didik tentang ide dengan jelas, tepat, dan ringkas. Kedua bahwa pembelajaran matematika merupakan aktivitas sosial yang menjadi wahana interaksi dan alat komunikasi yang melibatkan sedikitnya dua pihak yaitu guru dan siswa. Aktivitas sosial atau interaksi sosial dapat diterapkan melalui pembelajaran matematika sehingga siswa dapat meningkatkan kemampuan komunikasi matematisnya.

Adapun indikator-indikator kemampuan komunikasi menurut Kadir (dalam Hodiyanto, 2017:13) mengemukakan bahwa pengukuran kemampuan komunikasi matematis siswa dilakukan dengan memberika skor terhadap kemampuan siswa dalam:

a. Menulis (written text), yaitu menjelaskan ide atau solusi dari suatu permasalahan atau gambar dengan menggunakan bahasa sendiri.

b. Menggambar (drawing), yaitu menjelaskan ide atau solusi dari permasalahan matematika dalah bentuk gambar.

c. Ekspresi matematika (matematical ekpression), yaitu menyatakan masalah atau peristiwa sehari-hari dalam bahasa model matematika.

Mengingat penting kemampuan komunikasi matematika di sekolah dasar. Peneliti melakukan observasi di kelas III SD Negeri Kondangjaya I dengan hasil sebagai berikut: (1) proses pembelajaran di dominasi oleh guru sebagai penyampai informasi pada saat pembelajaran matematika guru menjelaskan dan memberikan contoh bagaimana harus menyelesaikan soal; (2) siswa kurang berkomunikasi dengan guru dalam proses mengajar karena siswa belajar dengan cara mendengar dan menonton guru; (3) rata-rata siswa yang pandai berhitung adalah siswa yang memiliki sifat pendiam; (4) Rata-rata siswa banyak yang terlihat tidak percaya diri ketika menjawab soal; (5) siswa terbiasa menjawab soal matematika secara singkat (6) guru kurang menerapkan beberapa model maupun metode pembelajaran.

Usaha untuk mengatasi masalah tersebut salah satunya adalah guru harus menciptakan suasana pembelajaran yang menyenangkan dan tidak membosankan. Kegiatan tersebut dapat tercipta apabila guru menggunakan model yang bervariasi dan media pembelajaran yang relevan dengan materi serta menggunakan pendekatan pembelajaran yang tepat sehingga siswa akan tertarik dengan mata pelajaran matematika. Salah satu model pemelajaran yang di dalamnya siswa belajar bekerja sama dengan cara berkelompok adalah model pembelajaran kooperatif.

Menurut Slavin (dalam Afandi, 2013:53), cooperative learning adalah "suatu model pembelajaran dimana siswa belajar dan bekerja dalam kelompok-kelompok kecil secara kolaboratif yang anggotanya 4-6 orang dengan struktur kelompok heterogen”. Dalam menyelesaikan tugas kelompok setiap anggota saling bekerja sama dan memantu untuk memahami suatu bahan pembelajaran. Sedangkan Menurut Tom V. Savage (dalam Huda, 2013:203) menyatakan bahwa "cooperative learning adalah suatu pendekatan yang menekankan kerjasama dalam kelompok". Pembelajara kooperatif ini sesuai dengan fitrah manusia sebagai makhluk sosial yaitu saling berinteraksi dan penuh ketergantungan dengan orang lain, mempunyai tujuan, rasa tanggung jawab. Seperti yang dijelaskan Abdulhak (dalam Huda, 2013:203) menyatakan bahwa "pembelajaran kooperatif dilaksanakan melalui sharing proses antara peserta belajar, sehingga dapat mewujudkan pemahaman bersama." Pembelajaran kooperatif dapat melatih 

matematis siswa sekolah dasar - Ayu Fitri, Ismaya Dewi

siswa untuk saling berbagi pengetahuan, pengalaman, tugas dan rasa tanggung jawab.

Tipe-tipe pembelajaran kooperatif ialah Jigsaw, Student Team Achievement Division (STAD), Numbered Heads Together (NHT), Make- a match (mencari pasangan), Talking Stick, Snowball Throwing (Fitri, 2018:45).

Menurut Suprijono (dalam Afandi, 2013:71) Merupakan tipe yang menggunakan kartu. Kartukartu tersebut terdiri dari kartu berisi pertanyaanpertanyaan dan kartu-kartu lainnya berisi jawaban dari pertanyaan-pertanyaan tersebut. Salah satu cara keunggulan teknik ini adalah siswa mencari pasangan sambil belajar mengenai suatu konsep atau topik, dalam suasana yang menyenangkan. Menurut Yatim (dalam Wandy. 2017:111) make a match adalah suatu model pembelajaran dengan cara siswa mendapat sepotong kartu yang berisi soal dan siswa tersebut mencari kartu lain yang berisi jawaban yang sesuai dengan soal yang diperolehnya. Model pembelajaran ini dapat membuat siswa lebih aktif dalam proses pembelajaran di dalam kelas. Anita Lie (dalam Budiyanto, 2016:156) menyatakan bahwa pembelajaran tipe Make A Match atau bertukar pasangan merupakan teknik belajar yang memberi kesempatan siswa untuk bekerja sama dengan orang lain. Teknik ini bisa digunakan dalam semua mata pelajaran dan untuk semua tingkatan usia anak didik. Model pembelajaran kooperatif tipe Make A Match adalah suatu teknik mencari pasangan sambil belajar mengenai suatu konsep atau topik dalam semua mata pelajaran dan tingkatan kelas. Model pembelajaran Make A Match dapat melatih siswa untuk berpartisipasi aktif dalam pembelajaran secara merata serta menuntut siswa bekerjasama dengan anggota kelompoknya agar tanggung jawab dapat tercapai, sehingga semua siswa aktif dalam proses pembelajaran. persiapan sebelum melakukan model pembelajaran kooperatif tipe make a match meliputi:

a. Membuat beberapa pertanyaan yang sesuai dengan materi yang dipelajari (jumlahnya tergantung dari tujuan pembelajaran) kemudian menulisnya dalam kartu-kartu pertanyaan.

b. Membuat kunci jawaban dari pertanyaanpertanyaan yang telah dibuat dan menulisnya dalam kartu-kartu jawaban, akan lebih baik apabila kartu pertanyaan dan kartu jawaban berbeda warna.

c. Membuat aturan yang berisi penghargaan bagi siswa yang berhasil dan sanksi bagi siswa yang gagal.

d. Menyediakan lembaran untuk mencatat pasangan pasangan yang berhasil sekaligus untuk penskoran presentasi.

Sintak model pembelajaran kooperatif tipe make a match menurut huda (2013:252) dapat dilihat pada langkah-langkah kegiatan pembelajaran berikut ini:

a. Guru menyampaikan materi atau memberi tugas kepada siswa untuk mempelajari materi di rumah

b. Siswa dibagi kedalam 2 kelompok, misalnya kelompok A dan kelompok B, kedua kelompok diminta untuk berhadap-hadapan

c. Guru membagikan kartu pertanyaan kepada kelompok A dan Kartu jawaban kepada kelompok B

d. Guru menyampaikan kepada siswa bahwa mereka harus mencari atau mencocokkan kartu yang dipegang dengan kartu kelompok lain. Guru juga perlu menyampaikan batasan maksimum waktu yang ia berikan kepada mereka (peserta didik).

e. Guru meminta semua anggota kelompok A untuk mencari pasangannya di kelompok B. jika mereka sudah menemukan pasangannya 

matematis siswa sekolah dasar - Ayu Fitri, Ismaya Dewi

masing-masing, guru meminta mereka melaporkan diri kepadanya. Guru mencatat mereka pada kertas yang sudah dipersiapkan.

f. Jika waktu sudah habis, mereka harus diberitahu bahwa waktu sudah habis. Siswa yang belum menemukan pasangan diminta untuk berkumpul tersendiri.

g. Guru memanggil satu pasangan untuk presentasi. Pasangan lain dan siswa yang tidak mendapat pasangan memperhatikan dan memberikan tanggapan apakah pertanyaan dan jawaban dari kartu tersebut cocok atau tidak.

h. Terakhir, guru memberikan konfirmasi tentang kebenaran dan kecocokan pertanyaan dengan jawaban dari pasangan yang memberikan presentasi.

i. Guru memanggil pasangan berikutnya, begitu seterusnya sampai seluruh pasangan melakukan presentasi.

Sedangkan langkah langkah pembelajaran make a match meurut Rusman (dalam Afandi, 2013: 71) adalah sebagai berikut:

a. Guru menyiapkan beberapa kartu yang berisi beberapa konsep atau topik yang cocok untuk sesi review, sebaliknya satu bagian kartu soal dan bagian lainnya kartu jawaban.

b. Setiap siswa mendapat satu buah kartu.

c. Setiap siswa memikirkan jawaban atas soal dari kartu yang dipegang.

d. Setiap siswa mencari pasangan yang mempunyai kartu yang cocok dengan kartunya (jawaban soal).

e. Setiap siswa yang dapat mencocokan kartunya sebelum batas waktu diberi point.

f. Setelah satu babak, kartu dikocok lahi agar setiap siswa mendapat kartu yang berbeda dari sebelumnya.

g. Kesimpulan
Maka dari penjelasan menurut para ahli tersebut langkah-langkah yang akan digunakan pada penelitian ini adalah (1) Guru menyampaikan materi; (2) Guru membagikan kartu jawaban dan kartu pertanyaan secara acak kepada siswa; (3) Guru menyampaikan kepada siswa bahwa mereka harus mencocokkan kartu yang dipegang dengan kartu milik siswa lain; (4) Guru meminta satu persatu siswa yang memegang kartu jawaban membacakan pertanyaannya dan siswa lain yang memegang pertanyaan memasangkan kartu; (5). Guru memberikan konfirmasi tentang kebenaran dan kecocokan pertanyaan dengan jawaban dari pasangan yang memberikan presentasi (6) setelah pertanyaan pertama selesai dijawab, maka siswa yang lain membacakan pertanyaan berikutnya. Selain itu Huda (2013:253) menyatakan bahwa pembelajaran kooperatif ini memiliki kelebihan serta kelemahan, Kelebihan model pembelajaran kooperatif tipe make a match ini yaitu: (1) Dapat meningkatkan aktivitas belajar siswa baik kognitif maupun fisik; (2) Karena ada unsur permainan, model pembelajaran ini sangat menyenangkan; (3) Meningkatkan pemahaman siswa terhadap materi yang dipelajari dan dapat meningkatkan motivasi belajar siswa; (4) Efektif sebagai sarana melatih keberanian siswa untuk tampil presentasi; dan (5) Efektif melatih kedisiplinan siswa menghargai waktu untuk belajar. Adapun kelemahan model kooperatif tipe make a match yaitu : (1) jika model pemelajaran ini tidak dipersiapkan dengan baik, akan banyak waktu yang terbuang; (2) Pada awalawal penerapan model pembelajaran ini, banyak siswa yang aka malu berpasangan dengan lawan jenisnya; (3) Jika guru tidak mengarahkan siswa dengan baik, akan banyak siswa yang kurang memperhatikan pada saat presentasi pasangan; (4) Guru harus hati-hati dan bijaksana saat memberi hukuman pada siswa yang tidak mendapat pasangan , karena mereka bisa malu; (5) 

matematis siswa sekolah dasar - Ayu Fitri, Ismaya Dewi

Menggunakan model pembelajaran ini secara terus-menerus akan menimbulkan kebosanan.

Dari pembahasan diatas maka dapat disimpulkan bahwa model pembelajaran kooperatif tipe make a match adalah suatu pembelajaran yang mencari pasangan sambil berjalan dengan menggunakan media kartu yang masing-masing kartu berisi kartu pertanyaan serta kartu jawaban. Model pembelajaran ini memiliki kelebihan yaitu: Dapat menumbuhkan kemampuan komunikasi, meningkatkan pemahaman siswa terhadap materi yang dipelajari, dapat meningkatkan motivasi siswa karna terdapat unsur permainan dalam pembelajaran, serta melatih kedisiplinan dan efektif sebagai melatih keberanian siswa. Selain kelebihan pembelajaran ini juga memiliki kelemahan yaitu: waktu akan banyak terbuang, siswa akan malu untuk berpasangan denngan lawan jenis, dapat menimbulkan kebosanan. Maka dari itu untuk mengatasinya guru harus mempersiapkan kegiatan ini dengan memperkirakan waktu yang akan digunakan, sehingga tidak banyak waktu yang terbuang, selain itu guru harus mampu membawa alur permainan dalam penerapan model pembelajaran ini dengan sangat menyenangkan sehingga siswa tidak merasa bosan.

Berkaitan dengan hal di atas, peneliti mencoba untuk melakukan suatu eksperiment pembelajaran matematika dengan menerapkan model pembelajaran yang melibatkan siswa aktif berkomunikasi. Maka dari itu saya sebagai peneliti mengambil judul "Pengaruh Model Pembelajaran Kooperatif Tipe Make A Match Terhadap Kemampuan Komunikasi Matematis Siswa Kelas III Sekolah Dasa.

\section{METODE}

Penelitian ini menggunakan pendekatan kuantitatif dengan jenis penelitian eksperimen semu (quasy eksperiment). Desain yang digunakan dalam penelitian ini adalah nonequivalent kontrol group design (Sugiyono, 2017:79). Dalam pelitian ini terdapat Variable bebas (Variable prediktor) yaitu model Cooperative Learning Tipe Make A Match dan Variable terikat (Variable Criteria) yaitu kemampuan komunikasi matematis pada siswa kelas III sekolah dasar.

$\begin{array}{cccc} & \text { Pada penelitian ini teknik } \\ \text { pengumpulan data yang digunakan berupa }\end{array}$
instrument tes kemampuan komunikasi matematis. Tes ini terdiri atas tes awal (pre test) dan tes pasca tindakan (post test). Tes awal diberikan sebelum melakukan tindakan yang bertujuan untuk mengukur kemampuan komunikasi matematis siswa sebelum diberikan tindakan. Sedangkan post test diberikan setelah dilakukan tindakan melalui model make a match yang bertujuan untuk mengukur komunikasi matematis siswa.

\section{HASIL DAN PEMBAHASAN}

Pada sub bab pembahasan hasil penelitian ini, akan dibahas mengenai data hasil perhitungan yang diperoleh selama proses penelitian berlangsung. Berikut pembahasan data hasil selama penelitian:

\section{Hasil Pretest Model Cooperative} learning Tipe Make A Match dalam peningkatan kemampuan komunikasi matematis dikelas eksperimen dan di kelas kontrol menunjukan hasil yang positif. 
Pengaruh model pembelajaran kooperatif tipe Make A Match terhadap kemampuan komunikasi matematis siswa sekolah dasar - Ayu Fitri, Ismaya Dewi

Tabel 1. Statistik Deskriptif Nilai Posttest

Kemampuan Komunikasi Matematis

\begin{tabular}{cccccc}
\hline & N & Minimum & Maksimum & Mean & $\begin{array}{c}\text { Std. } \\
\text { Deviation }\end{array}$ \\
\hline Eksperimen & 30 & 65 & 93 & 76.90 & 6.804 \\
Kontrol & 30 & 60 & 85 & 71.53 & 5.277 \\
\hline
\end{tabular}

Kelas eksperimen Menggunakan Model Cooperative learning Tipe Make A Match, sedangkan kelas kontrol Tanpa menggunakan Model Cooperative learning Tipe Make A Match

Dari Tabel di atas dapat diketahui bahwa nilai Posttest pada kelas eksperimen dengan jumlah 30 siswa, memiliki nilai maksimal yang diperoleh 93, nilai minimal 65, nilai rata-ratanya 76,90, dan standar deviasi adalah 6,804. Kelas kontrol yang terdiri dari 30 orang siswa, memiliki skor maksimal 85, skor minimal 60, serta memiliki rata-rata 71,53 dan standar deviasi adalah 5,277.

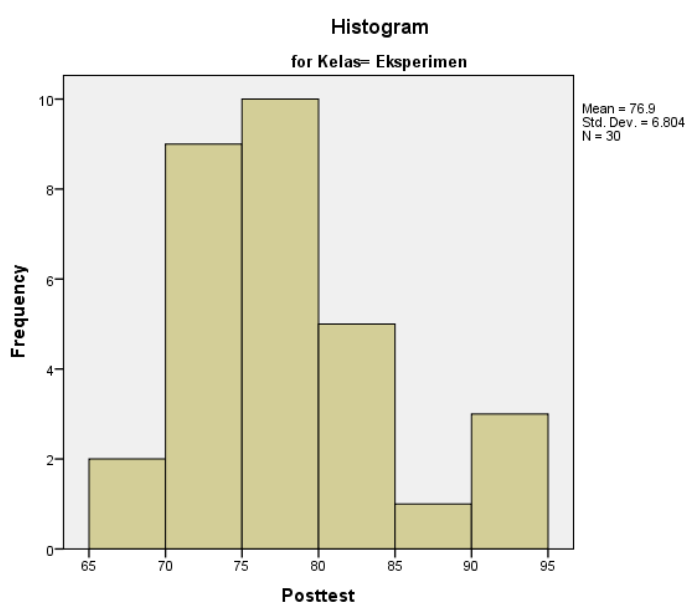

Gambar 1. Grafik Nilai Rata-rata Posttest Kelas Eksperimen

Berdasarkan tabel dan grafik diatas, dapat diketahui bahwa siswa yang mendapatkan nilai 65 - 79 sebanyak 2 orang, 70 - 74 sebanyak 9 orang siswa, 75-79 sebanyak 10 orang siswa, $80-44$ sebanyak 5 orang siswa, 85 - 89 sebanyak 1 siswa, dan 90 - 94 sebanyak 3 orang siswa. Hipotesis menunjukan bahwa nilai probabilitas (signitifikan) adalah 0,001. Karena nilai signitifikansi $0,001<\alpha=0,05$. Hal ini membuktikan bahwa kelas yang menggunakan model pembelajaran kooperatif tipe make a match terhadap kemampuan komunikasi matematis memiliki perbedaan pengaruh daripada kelas yang tidak menggunakan model pembelajaran kooperatif tipe make a match.

Berdasarkan hasil penelitian dapat disimpulkan bahwa terdapat perbedaan pengaruh yang siginfikan mengenai kemampuan komunikasi matematis siswa antara kelas eksperimen yang diberi perlakuan dan kelas kontrol yang tidak diberi perlakuan. Penelitian yang dilakukan di SDN Kondangjaya III Kec. Karawang timur Kab. Karawang pada materi keliling bangun datar kelas III tahun ajaran 2018/2019 dengan hasil pengujian dengan menggunakan uji-t 2 tailed yaitu $\leq 0.05$. Hasil analisis data pada pretest kelas eksperimen nilai yang didapat masih rendah nilai yang diperoleh sebesar 38.20, sedangkan pada kelas kontrol adalah 39.00. Setelah dilakukan treatment pembelajaran menggunakan model pembelajaran kooperatif tipe make a match. Hasil analisis pada posttest kelas eksperimen diperoleh bahwa kemampuan komunikasi matematis siswa meningkat dengan rata-rata menjadi 76.90, sedangkan pada kelas kontrol diperoleh nilai ratarata 71.53. Berdasarkan uji $\mathrm{t}$ yang dilakukan diperoleh sig (2-tailed) $<0.05$ yang artinya terdapat perbedaan terhadap kemampuan komunikasi matematis siswa. 

matematis siswa sekolah dasar - Ayu Fitri, Ismaya Dewi

\section{DAFTAR PUSTAKA}

Afandi. 2013. Model dan Metode Pembelajaran Di Sekolah. Semarang: UNISSULA PRESS

Akib Irwan. 2015. Implementasi Teori Belajar Robert Gagne Dalam Pembelajaran Konsep Matematika. Makasar : Lembaga Perpustakaan dan Penerbitan.

Aliputri Dhestha Hazilla. 2018. Penerapan Model Pembelajaran Kooperatif TipeMake A Match Berbantuan Kartu Bergambar Untuk Meningkatkan Hasil Belajar Siswa.Budiyanto Agus Krisno. 2016. SINTAKS 45 Model Pembelajaran Dalam Student Centered Learning (SCL). Malang: Universitas Muhammadiyah Malang.

Fitri, Ayu. 2018. Model Pembelajaran Matematika di Sekolah Dasar. Karawang: FBIS PublishingHelmiati. 2012. Model Pembelajaran. Yogyakarta: Aswaja Pressindo

Hodiyanto. 2017. Kemampuan Komunikasi Matematis Dalam Pembelajaran Matematis. Vol. 7 No.1 ISSN:2088687X, Huda M. 2013. Model-Model Pengajaran Pembelajaran. Yogyakarta : PUSTAKA PELAJAR. Inten Dinar Nur. 2017. Pengembangan Keterampilan Berkomunikasi Anak UsiaDini Melalui Metode Bermain Peran. Vol 10 (1).

Jailani, dkk. 2018. Desain Pembelajaran Matematika. Yogyakarta : UNY PRESS

Lestari Dania Fuji. 2013. Meningkatkan Kemampuan Komunikasi Matematis

Siswa Dalam Menyelesaikan Soal Cerita Melalui Pendekatan Pemecahan Masalah. Jurnal Pendidikan Volume 14 Nomor 2.

Murti Rahayu Condro. 2009. Meningkatkan Kemampuan Matematika Di Sekolah Dasar Dengan Menggunakan Model Pembelajaran Sosiokultur. Volume 02, Nomor 2,

Purnama Martini Dwi. 2017. Pengembangan Media Box Mengenal Bilangan Dan Operasinya Bagi Siswa Kelas 1 Di SDN Gadang 1 Kota Malang. Volume 1 Nomor 1.
Sari Ika Puspita. 2017. Kemampuan Komunikasi Matematika Berdasarkan Perbedaan Gaya Belajar Siswa Kelas X SMA Negeri 6 Wajo Pada Materi Statistika. Volume 5 Nomor 2.

Sugiyono. (2017). Metode Penelitian Kuantitatif, Kualitatif, dan R\&D. Bandung : ALFABETA, CV.

Wandy. 2017. Metode Pembelajaran Make A Match Untuk Meningkatkan Hasil Belajar Bahasa Indonesia Siswa Sekolah Dasar Menengah Pertama. Vol.3 No 1.

Yurniati Yeni. 2014. Pengembangan Kemampuan Komunikasi Matematis Dalam Pembelajaran Matematika Di Sekolah Dasar. Vol. 6 No 2. 